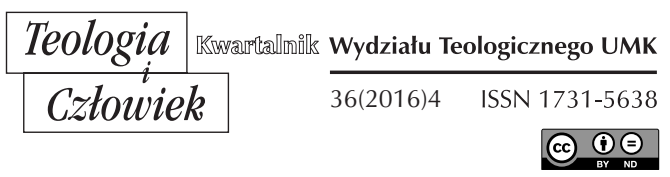

KS. SŁAWOMIR TYKARSKI*

TORUŃ

\title{
ZROZUMIENIE ISTOTY MISTYCZNEGO MAŁŻEŃSTWA JEZUSA I ŚW. SIOSTRY FAUSTYNY JAKO PROLOG DO DALSZYCH ROZWAŻAŃ NA TEMAT KSZTAŁTOWANIA MlŁOŚCl I RELACJI MAŁŻEŃSKICH.
}

DOI: http://dx.doi.org/10.12775/TiCz.2016.050

Przyglądając się tytułowi artykułu, czytelnik może się zastanawiać, czy tak dwie różne rzeczywistości, jakimi są mistyczne małżeństwo i relacje małżeńskie w ogóle mają ze sobą coś wspólnego i czy tak odmienne rzeczywistości można ze sobą zestawić? Należy zaznaczyć, że niniejsze opracowanie jest pierwszą częścią dyptyku i dopiero w drugiej znajduje się odpowiedź i jej uzasadnienie ${ }^{1}$. W tej części, która przyjmuje formę prologu, zostanie wyjaśnione czym jest mistyczne małżeństwo i jak się ono kształtowało między Jezusem a św. Siostrą Faustyną.

* Ks. dr Sławomir Tykarski jest adiunktem w Katedrze Teologii Praktycznej Wydziału Teologicznego UMK (tykarek@gmail.com).

${ }^{1}$ Druga część zostanie opublikowana w następnym numerze „Teologia i Człowiek". 


\section{ISTOTA DUCHOWEGO MAŁŻEŃSTWA}

Według Encyklopedii katolickiej zaślubiny duchowe to „stan mistyczny zjednoczenia duszy z Bogiem w stopniu najwyższym o znamionach duchowego przeobrażenia często poprzedzony zaręczynami mistycznymi [...]. Mistyk [...] doświadcza trwałego pokoju wewnętrznego, szczęścia, rozwoju cnót oraz heroicznej gorliwości apostolskiej. Bóg udziela się duszy jako czynnik poruszający nie tylko wolę, lecz całą jej istotę, a także obejmuje kierownictwo nad jej życiem (Ga 2,20); ze strony przeżyć człowieka wyodrębnia się przygotowujące do zaślubin duchowych etapy związane z miłością Boga, zjednoczenie z Jego miłością, zrównanie $\mathrm{z}$ nią, doświadczenie ran ze strony miłości, przeżywanie wiecznego święta w miłości; ponadto człowiek doświadcza integracji na wszelkich poziomach egzystencji - z Bogiem, ludźmi i samym sobą; osiąga też pełnię życia cnotami teologalnymi: wiary, nadziei, miłości oraz aktualizację dzięcięctwa i usynowienia Bożego"2.

Mistyczne zaślubiny wiążą się ściśle ze zjednoczeniem z Bogiem. Akt ten stanowi najdoskonalszy wyraz miłości oblubieńczej między Stwórcą a stworzeniem. Według św. Jana od Krzyża polega on na całkowitym podporządkowaniu ludzkiej duszy (woli) z Bożą wolą ${ }^{3}$. Dzieje się to poprzez oczyszczenie zmysłów (tzw. noc zmysłów) oraz oczyszczenie ducha (tzw. noc ducha). Cały ten proces przebiega w powiązaniu z osobistym zaangażowaniem duszy, co przyjmuje miano nocy czynnej, jak również opiera się na Bożej interwencji podczas nocy biernej. „Stan zjednoczenia mistycznego obejmuje duchowe zaślubiny ${ }^{4}$ oraz małżeństwo; zaślubiny są pełnią zgody duszy z wolą Bożą, co dokonuje się podczas nocy ducha i prowadzi do jednoczącej kontemplacji, będącej owocem darów Ducha Świętego; pokusy ustępują dopiero w małżeństwie duchowym, w którym dusza odczuwa stałą obecność Boga w sobie" ${ }^{5}$. Działanie Ducha Świętego

2 T. Paszkowska, Zaślubiny duchowe, w: Encyklopedia katolicka, t. XX, Lublin 2014, k. 1263.

${ }^{3}$ Zob. Dz 372, 374.

${ }^{4}$ Niekiedy używa się terminu „mistyczne zaręczyny” bądź „zaręczyny duchowe”.

${ }^{5}$ J. Misiurek, Mistyka, w: Encyklopedia katolicka, t. XII, Lublin 2008, k. 1318. Siostra Faustyna była w sposób zupełny uwolniona od pokus cielesnych: „Kiedy wyszłyśmy z klęczników i zaczęłyśmy mówić formułę ślubów, nagle stanął Jezus obok mnie 
powoduje wniknięcie do duszy Bożego światła, które pozwala na poznanie Boskich tajemnic ${ }^{6}$. Według św. Tomasza z Akwinu dzieje się to dzięki darom Ducha Świętego ${ }^{7}$. Wówczas człowiek przeciwstawia się złu, czyniąc dobro i w sposób całkowity oddaje się Bogu.

W zjednoczeniu mistycznym szczególną rolę pełni miłość ekstatyczna prowadząca duszę ku Bogu i będącą podstawą relacji z Nim; zjednoczenie w miłości ma charakter uczuciowy i rodzi świadomość obecności w duszy Osób Boskich; ma ono miejsce po długim procesie oczyszczeń; przygotowanie duszy, w której światło zmaga się z ciemnością, opisuje Jan od Krzyża, mówiąc o całkowitym zaniechaniu aktywności władz wyobraźni, intelektu i woli w celu uwolnienia zmysłów od trosk i pragnień wiążących ze światem materialnym; do osiągnięcia tego prowadzi rezygnacja i całkowite umartwienie odrywające człowieka od rzeczy zmysłowych i kierujące do duchowych [...] całkowite uwolnienie się człowieka od przyziemnych pożądań wymaga pomocy Boga, który sprawia najpierw całkowitą pustkę i ciszę w duszy; bierne oczyszczenie wiąże się z bolesnymi dla duszy próbami odrywającymi ją od rzeczy stworzonych; działanie Boga przyjmowane przez człowieka w sposób bierny nazywa się nocą, będącą dla duszy czasem duchowych ciemności i niemocy, przez które ona przechodzi ${ }^{8}$.

Pojęcie zaślubin mistycznych nosi również nazwę zjednoczenia przemieniającego. Według św. Jana od Krzyża i św. Teresy jest to najważniejszy rozwój życia łaski w duszy, jaki można zaznać na ziemi ${ }^{9}$. Jest to stan doskonały życia duchowego, rozwoju cnót i darów oraz punkt

w szacie białej, przepasany pasem złotym i rzekł do mnie: udzielam ci wieczystej miłości, aby czystość twoja była nieskalana i na dowód, że nie będziesz nigdy doznawać pokus nieczystych - zdją Jezus pas zloty z siebie i przepasał nim biodra moje. Od tej chwili nie doznaję żadnych poruszeń przeciwnych cnocie ani w sercu, ani w umyśle" (Dz 40). Odnośnie przykładów odczuwania obecności Bożej zob. Dz 26, 42, 135, 137, 142, 147, 154.

${ }^{6}$ Przykłady tajemnic, którymi dzieli się Jezus z Faustyną mogą dotyczyć np. wyglądu piekła (Dz 741), czyśćca (Dz 20), losu Polski (Dz 1732), misji, jaką ma odegrać w świecie i ludzkości Boże Miłosierdzie (Dz 154, 177, 420, 570).

7 Tomasz z Akwinu, Suma teologiczna, I-II q.68, a.2.

8 J. Machniak, Zaślubiny duchowe, w: Mistyka, w: Encyklopedia katolicka, t. XII, Lublin 2008, k. 1322-1323.

9 Zob. R. Garrigou-Lagrange, Trzy okresy życia wewnętrznego wstępem do życia w niebie, Niepokalanów 2001, s. 837. 
kulminacyjny miłości Boga i najściślejsze zjednoczenie z Trójcą Świętą ${ }^{10}$. To posiadanie Boga przez zjednoczenie się z Nim w miłości. Zjednoczenie przemieniające ma różne stopnie. Dwa z nich noszą nazwy duchowych zaręczyn i duchowych zaślubin (małżeństwo duchowe) ${ }^{11}$. Różnica między nimi polega na czasie trwania zjednoczenia. W pierwszym przypadku dusza raduje się ze zjednoczenia w sposób przejściowy, podczas gdy w zaślubinach cieszy się ona w sposób prawie ciągły. Niesie to za sobą pewne skutki. Zjednoczenie przemieniające powoduje w duszy wzrost miłości Bożej, Jego opieki, która usuwa okazje do grzechu i daje duszy siłę do pokonywania grzechów tak, że jest ona zachowana na zawsze od grzechu śmiertelnego, jak i prawie zawsze dobrowolnego grzechu powszedniego ${ }^{12}$. Ponadto dusza zupełnie zapomina o sobie, odczuwając wielkie pragnienie cierpienia na wzór Jezusa Chrystusa. Cechuje się ogromną miłością do bliźniego, potrafi połączyć cnoty na pozór się wykluczające tzn. sprawiedliwość z miłosierdziem, prostoty gołębicy i roztropności węża, życie kontemplacyjne ze zmysłem praktycznym.

Nie można pominąć jeszcze istotnego faktu związanego ze zjednoczeniem przemieniającym, a mianowicie jest to całkowity dar od Boga dusza przy pomocy swoich wysiłków nie może go uzyskać. Jednoznacznie podkreślała to św. Teresa w Twierdzy wewnętrznej, mówiąc do sióstr:

Nie do wszystkich jednak Mieszkań tej Twierdzy o własnych siłach, chociażby się wam zdawały dużymi, dostać się możecie, jeśli was Pan Twierdzy sam do nich nie wprowadzi. Dlatego ostrzegam was, gdybyście znalazły drzwi zamknięte, nie próbujcie dobijać się siłą; mógłby się o to zagniewać Pan i już by was nigdy nie wpuścił. On bardzo lubi pokorę.

${ }_{10}$ Zob. Jan od Krzyża, Żywy płomień miłości, strofa 2; Pieśń duchowa, cz. III, strofa 22n. Obcowanie z Trójcą Świętą było również udziałem św. Siostry Faustyny. Opisuje to w Dzienniczku: „W pewnej chwili po Komunii św. usłyszałam te słowa: Tyś jest Nam mieszkaniem. W tej chwili odczuwałam w duszy obecność Trójcy Świętej Ojca, Syna i Ducha Świętego - czułam się świątynia Bożą, czuję, że jestem dzieckiem Ojca; nie umiem wytłumaczyć wszystkiego, ale duch to dobrze rozumie. O dobroci nieskończona, jak bardzo zniżasz się do nędznego stworzenia” (Dz 451). Zob. też Dz 27, 30, 392, 472, 474, 911, 955, 961, 1129, 1670.

11 Zob. Jan od Krzyża, Pieśń duchowa, strofa 14.

12 Zob. R. Garrigou-Lagrange, Trzy okresy, s. 842. Zob. Dz 338. 
Ponadto dusza, która łączy się z Panem w małżeństwie duchowym, zanim to nastąpi, musi przejść przez ogrom cierpień. Podkreślał to św. Jan od Krzyża w słowach: „O dusze, które chcecie chodzić spokojnie pełne zadowolenia $w$ rzeczach duchowych, gdybyście wiedziały, ile wam trzeba znieść cierpień, aby przyjść do tego pokoju i zadowolenia"13.

Ach gdyby raz zrozumiano, że nie można dojść do głębi mądrości i bogactw Bożych inną drogą, jak tylko przez gąszcze cierpień i tysiące udręczeń. W nich więc powinna znaleźć radość dusza! Im bowiem większej pragnie mądrości od Boga, tym bardziej winna najpierw pragnąć cierpienia, by przez nie wejść w ukrycie Krzyża, który prowadzi do życia... By wejść do tych bogactw mądrości, trzeba przejść przez ciasną bramę... Zaś niewielu pragnie przez nią wchodzić, natomiast wielu pragnie rozkoszy i przez nią chce iść do Boga ${ }^{14}$.

Życie św. Faustyny było naznaczone ogromem cierpień, które przeżywała z miłości do Jezusa i do bliźnich (zwłaszcza tych trudnych) ${ }^{15}$. Niejednokrotnie swoje cierpienia ofiarowywała za grzeszników (np. Dz 72, 206, 246, 280, 308, 309, 319, 349, 384, 648), dusze cierpiące w czyśćcu (Dz 58, 240, 274, 346, 412, 692, 1226, 1723, 1738 bądź wprost cierpienia innych brała na siebie (Dz 41, 163, 192, 291, 311). Podczas obłóczyn, czyli obrzędu ubierania po raz pierwszy habitu, Jezus dał poznać Faustynie ile będzie musiała cierpieć (Dz 22) ${ }^{16}$. Niemniej każde cierpienie Faustyna

${ }^{13}$ Jan od Krzyża, Żywy płomień miłości, strofa 2, w. 5.

${ }^{14}$ Cyt. za R. Garrigou-Lagrange, Trzy okresy, s. 851.

${ }^{15}$ Siostra Faustyna wiele musiała znieść cierpień i przykrości od współsióstr, które nie dawały wiary w jej obcowanie z Bogiem i wizje, które miała. Z tego względu nie darzyły jej sympatią, co miało odzwierciedlenie w jej wyśmiewaniu, obmowach, stronieniu od niej bądź upokarzaniu. Przykładem tego są fragmenty z „Dzienniczka”: „Dziś sprzątałam pokój jednej z sióstr. Pomimo że się starałam go sprzątać z największym staraniem, jednak osoba ta przez cały czas sprzątania chodziła za mną i mówiła - tu proszek, tam plamka na podłodze. Na każde jej skinienie poprawiałam choć dziesięć razy to samo, byle ją zadowolić. Nie praca męczy, ale te nieumiarkowane gadania i wymagania. Nie wystarczyło jej moje całodzienne męczeństwo, ale poszła do Mistrzyni na skargę. Proszę Matki, co to za siostra niedokładna, nie umie się pospieszać. Na drugi dzień poszłam tę sama robotę robić bez słowa tłumaczenia. Kiedy mnie wzięła w swoje obroty, to pomyślałam sobie: Jezu, można być cichą męczennicą - nie od pracy sił ubywa, ale tego męczeństwa. (Dz 181)”. Zob. też Dz 29, 128, 151, 165, 167, 168, 171, 1727.

${ }^{16}$ Podczas obłóczyn i pod wpływem wizji o przyszłych cierpieniach siostra Fau- 
przyjmowała $\mathrm{w}$ pokorze i $\mathrm{z}$ ochotą serca, nie zrażając się ich wielkością wymagającą poświęcenia $\mathrm{z}$ aktami pokuty i umartwień. Jej cierpienie było ściśle związane z miłością do Chrystusa, o czym mogą świadczyć słowa:

Kiedy raz miałam jedno cierpienie wielkie, uciekałam od obowiązku do Pana Jezusa i prosiłam, aby mi udzielił swej mocy. Po króciutkiej modlitwie wróciłam do obowiązku pełna zapału i radości. W tym mi mówi jedna $\mathrm{z}$ sióstr, że pewno siostra dziś ma wiele pociech, bo taka siostra jest rozpromieniona. Bóg pewno siostrze nie daje żadnego cierpienia - tylko same pociechy. Odpowiedziałam - myli się siostra bardzo, bo właśnie wtenczas, kiedy wiele cierpię, to i radość moja większa, a kiedy mniej cierpię to i radość moja mniejsza. Jednak ta dusza dawała mi poznać, że mnie w tym nie rozumie. Starałam się jej to wytłumaczyć: kiedy cierpimy wiele, to mamy sposobność wielką okazać Bogu, że Go kochamy, a kiedy cierpimy mało, to mamy mało sposobności, by okazać Bogu swą miłość, a kiedy nie cierpimy nic, to miłość nasza nie jest wielka ani czysta. Możemy dojść za łaska Bożą do tego, że cierpienie dla nas zamieni się w rozkosz, bo miłość umie takie rzeczy działać w duszach czystych (Dz 303).

Ujmując jednym zdaniem, wszelkie formy cierpień stały się dla Faustyny stałymi towarzyszkami (zob. Dz 316).

\section{CÓRKA CZY OBLUBIENICA?}

Poddając analizie treść Dzienniczka pod kątem określeń, jakim Jezus nazywał siostrę Faustynę, można zauważyć, że o wiele częściej zwracał się do niej mianem „córko” niż „oblubienico”. Sformułowanie „córko” („moja”; „umiłowana”) pojawia się aż 197 razy, podczas gdy mianem

styna zemdlała. Świadkiem tego zdarzenia była siostra M. Klemensa Buczek, która pomagała Faustynie przy ubiorze habitu. Tak wspomina to wydarzenie: „ «Helenko, spieszmy się, zdejmujmy tę suknię, aby włożyć habit. Bierzmy się do roboty». Helenka zemdlała, pobiegłam po wodę kolońską. Gdy wróciłam, ona już ocuciła się trochę, spieszyć trzeba, więc mówię: «No, Helenko, ucałować mocno ten habit, żebyś w nim do śmierci Panu Jezusowi służyła». Ucałowała serdecznie, a ja jej jeszcze dokuczałam w żartach: «Tak za światem żałuję, że aż mdleje!». I śmiałyśmy się trochę obie”. Wspomnienia o świętej Siostrze Faustynie Kowalskiej ze Zgromadzenia Matki Bożej Miłosierdzia, wyd. 2, Kraków 2015, s. 184. Na temat cierpienia zob. też Dz 36, 73, 104, 190, 192, 488, 675, 918, 1626. 
„oblubienicy” nazywa Faustynę tylko sześciokrotnie ${ }^{17}$. Jedyny raz Chrystus sam się nazywa jej oblubieńcem ( $\mathrm{Dz}$ 1770). Natomiast Faustyna nazywa Jezusa swoim oblubieńcem $31 \mathrm{razy}^{18}$, a siebie - Jego oblubienicą dziesięciokrotnie $^{19}$. Z powyższych statystyk może zrodzić się pytanie czy bardziej istotne jest dzięcięctwo Faustyny, czy stan duchowego małżeństwa? Przyglądając się treści Dzienniczka, a szczególnie fragmentom, w których siostra Faustyna jest nazwana przez Jezusa córką, można zauważyć, że dzieje się to w sytuacjach pedagogicznych, tzn. gdy Chrystus chce coś jej przekazać, pouczyć, zwrócić na coś uwagę, dać polecenie lub oznajmić jakąś prawdę o sobie ${ }^{20}$. Ponadto owo sformułowanie jest używane, gdy Zbawiciel chce uspokoić zalęknione sumienie i serce Faustyny, tworząc klimat i poczucie bezpieczeństwa, opieki zwłaszcza, gdy przeżywa ona rozterki i chwile niepewności ${ }^{21}$. W tych momentach Pan Jezus bardzo mocno podkreśla swoją obecność, wskazując na swoją opatrzność, którą otacza Faustynę, jak również oznajmia kim dla Niego jest, ile znaczy i jaką rolę pełni $^{22}$. Jezus jawi się jako ojciec i wychowawca. Sama Faustyna tak też Go traktuje, a nawet idzie jeszcze dalej, przyrównując działania Chrystusa do matczynych zachowań ${ }^{23}$.

Odnośnie do duchowego małżeństwa nie znajdzie się w Dzienniczku zbyt wielu fragmentów. W uproszczeniu można powiedzieć, że centralnym i koronnym momentem jest złożenia przez Faustynę ślubów wieczystych (Dz 178, 184, 199, 248). Niemniej tego wydarzenia nie można utożsamiać z małżeństwem duchowym, bowiem każda zakonnica poprzez fakt ślubów staje się oblubienicą Chrystusa. W duchowym małżeństwie bycie oblubienicą przybiera o wiele głębszą formę, polegającą na ścisłym

17 Zob. Dz 158, 239, 348, 534, 1543, 1563.

${ }_{18}$ Zob. Dz 16, 25, 184, 240(x3), 244, 338, 343, 501, 591, 660(x2), 679, 654, 801, 832, 876, 885, 1064(x2), 1230(x2), 1330, 1553, 1632, 1653, 1771, 1786, 1805(x2).

19 Zob. Dz 220, 389, 392, 867, 1304, 1418, 1502, 1589, 1805, 1806.

${ }^{20}$ Zob. Dz 71, 156, 157, 167, 206, 548, 570, 612, 639, 699, 848, 894, 1074, 1142, 1146, 1565, 1567, 1572, 1599, 1685, 1760, 1777, 1782, 1797.

${ }^{21}$ Zob. Dz 103, 133, 152, 215, 219, 431, 626, 757, 797, 881, 1109, 1133, 1491, 1605

${ }^{22}$ Zob. Dz 151, 238, 268, 339, 954, 1058, 1176, 1182, 1193, 1664, 1754, 1774, 1816.

${ }^{23}$ Zob. Dz 23, 24, 27, 104, 230, 239, 242, 249, 357, 451, 606, 626, 629, 854, 1490, 1726, 1818. 
zjednoczeniu z Bogiem, czyli zjednoczeniu przemieniającym ${ }^{24}$. Polega ono na obcowaniu z Bogiem $\mathrm{w}$ relacjach bardzo bliskich. Oprócz widzenia osoby Jezusa, słyszenia Jego głosu, najistotniejsze jest totalne oddanie siebie i swojej woli pod Jego kierownictwo. Dzieje się to wszystko w najwyższej jednoczącej miłości i zażyłości. Takie zjednoczenie trudno jest opisać, gdyż wymyka się ono niejako naturalnemu poznaniu ${ }^{25}$. Stąd też mistyczne zjednoczenie, czyli duchowe małżeństwo przewyższa wszelkie inne formy kontaktu z Bogiem i Jego poznania. Faustyna jednak w taki wyjątkowy sposób była zjednoczona z Jezusem, o czym pisze na kartach Dzienniczka. Fragment ten jest najlepszym opisem jej mistycznego małżeństwa $\mathrm{z}$ Jezusem:

O jedenastej Jezus rzekł do mnie: hostio Moja, tyś jest Mi ochłodą dla udręczonego serca Mojego. Myślałam, że po tych słowach spali się serce moje. I wprowadził mnie $\mathrm{w}$ tak ścisłą łączność $\mathrm{z}$ sobą i zaślubiło się serce moje z Jego Sercem w sposób miłosny i odczułam Jego najlżejsze drgnienia, a On moje. Ogień mojej miłości, stworzony, został złączony z żarem wiekuistej miłości Jego. Wszystkie łaski ta jedna przewyższa swym ogromem. Troistość Jego ogarnęła mnie całą i jestem cała zanurzona w Nim; mocuje się niejako moja maleńkość z tym Mocarzem nieśmiertelnym. Jestem zanurzona $\mathrm{w}$ niepojętej miłości i w niepojętej męczarni z powodu Jego męki. Wszystko, co się dotyczy Jego Istoty, i mnie się udziela (Dz 1056) ${ }^{26}$.

${ }^{24}$ Zob. R. Garrigou-Lagrange, Trzy okresy, s. 849-850.

25 Sama Faustyna tak ten stan opisywała: „Kiedy myślę o tym, że Bóg łączy się ze mną przez śluby, czyli ja z Nim - pojąć tego nikt nie zdoła - czego doznaje serce moje. Już teraz daje mi Bóg poznanie całego ogromu swej miłości, jaką mnie kochał jeszcze przed wiekami, a ja Go zaczęłam kochać w czasie dopiero. Jego miłość była wielka, czysta i bezinteresowna, a moja miłość ku Niemu jest z poznania Go. Im Go więcej poznaję, tym goręcej i mocniej kocham i czyn mój doskonalszy jest. Jednak kiedy wspomnę sobie, że za parę dni mam się stać jedno z Panem przez ślub wieczysty, radość zalewa moja duszę tak niepojęta, że nie umiem tego wcale opisać. Przy pierwszym poznaniu Pana utonął wzrok mej duszy w Nim na wieki. Z każdym zbliżeniem się do mnie Pana - a przez to jest z mojej strony głębsze poznanie - rośnie w duszy miłość doskonalsza” (Dz 231).

${ }^{26}$ Inny fragment opisujący mistyczne małżeństwo brzmi następująco: „Wtem usłyszałam słowa sformułowane, słowa te są takie: chcę cię poślubić sobie. Jednak lęk przeszedł moją duszę, lecz bez niepokoju rozważałam, co by to za zaślubiny były, jednak za każdym razem lęk przenika duszę moją, ale jest spokój w duszy utrzymywany wyższą siłą. Przecież śluby wieczyste mam i przecież złożyłam ze szczerą i całkowitą wolą i wciąż 
Przyglądając się małżeństwu naturalnemu, można z całą pewnością stwierdzić, że żaden człowiek w sposób samoistny nie jest przygotowany do pełnienia roli żony czy męża. Dziecko, wychowując się w rodzinie poprzez przekazywane wartości, kształcenia osobowości, obserwację swoich rodziców, oddziaływania edukacyjne i środowisko, powoli dojrzewa (i to nie zawsze) do podjęcia funkcji małżeńskich. Kościół nazywa ten etap przygotowaniem dalszym do małżeństwa ${ }^{27}$. W analogiczny sposób można wysnuć wniosek, że Jezus jako wychowawca i kierownik siostry Faustyny przygotowywał ją do duchowego małżeństwa (zob. Dz 1771). Wszelki rodzaj doświadczeń codziennej egzystencji, jak również działanie Jezusa w duszy Faustyny, a także jej współpraca z łaską Bożą poprzez ekstremalne posłuszeństwo ${ }^{28}$, pokorę i dzięcięctwo wiążące się z bezgranicznym zaufaniem podyktowane miłością, stały się przestrzenią przygotowującą do duchowego małżeństwa. W ten sposób postawione wcześniej pytanie czy św. Faustyna była bardziej córką, czy oblubienicą nie do końca odnajduje swoje uzasadnienie. Jedno bowiem nie wyklucza drugiego, lecz uzupełnia. Świadomość i poczucie bycia dzieckiem Boga dało grunt do zjednoczenia przemieniającego, do wejścia w tak ścisłe relacje z Jezusem. Dzieje się to dzięki połączeniu przez Jezusa dwóch funkcji, które w Nim

rozważam, co to ma znaczyć; czuję i przenikam, że to jest jakaś łaska wyjątkowa. Kiedy ją rozważam, omdlenie mnie ogarnia za Bogiem, lecz w tym omdleniu jest umysł jasny i przeniknięty światłem. Kiedy jestem z Nim złączona, mdleję z nadmiaru szczęścia, lecz umysł mój jest jasny i czysty, bez przymieszek. Zniżasz swój Majestat, aby obcować z biednym stworzeniem. Dziękuję Ci, o Panie, za tę wielką łaskę, która mnie czyni zdolną do obcowania z Tobą. Jezu, Twoje imię jest mi rozkoszą, wyczuwam z daleka swego Umiłowanego, a stęskniona moja dusza odpoczywa w objęciach Jego, nie umiem żyć bez Niego, wolę z Nim być w mękach i cierpieniu, aniżeli bez Niego w największych rozkoszach nieba" (Dz 912). Zob. też Dz 411, 882.

27 Zob. Konferencja Episkopatu Polski, Dyrektorium duszpasterstwa rodzin, Warszawa 2003, nr 18-23.

${ }^{28}$ Przykładem bezgranicznego posłuszeństwa, jakie miała św. Faustyna względem Jezusa jest fragment listu zakonnicy do swojego spowiednika ks. Michała Sopoćki: „Jeszcze parę słów pragnę Drogiemu Ojcu, powiedzieć, ponieważ list ten napisałam 11 kwietnia, ale wysyłam dopiero 15 kwietnia, dlatego że czekałam na wyraźną wolę Bożą czy wysłać, czy nie”. Listy świętej Siostry Faustyny, wyd. 2, Kraków 2005, s. 82. Inne przykłady posłuszeństwa siostry Faustyny zob. Dz 24, 28, 68, 77, 105, 151, 354, 362, 365 , $381,615,624,645,894,895,933,961,979,1023,1069,1187,1267,1312,1374,1378$, $1567,1644,1650$. 
się nie kłócą i nie wykluczają - Chrystus bowiem jak jeden Bóg może być naraz i rodzicem (wychowawcą) i oblubieńcem.

Powyższe rozważania miały na celu przybliżyć istotę mistycznego małżeństwa, na czym ono polega i czym się charakteryzuje. Jak zostało zaprezentowane, św. siostra Faustyna była oblubienicą Chrystusa, z którym wiązało ją mistyczne małżeństwo. Jest ono szczególnym zjednoczeniem człowieka z Bogiem. Wiąże się z nim wiele łask, ale również niemało trudności a nawet cierpień. Siostra Faustyna przyjmowała wszystkie doświadczenia w duchu ogromnej pokory, posłuszeństwa, ufności, zawierzenia realizującego się w całkowitym poddaniu własnej woli pod wolę Bożą. Takie zachowanie stało się fundamentem do budowania głębokich relacji z Jezusem osiągające swój szczyt w mistycznym małżeństwie.

Streszczenie. Przyglądając się tytułowi artykułu, czytelnik może się zastanawiać czy tak dwie różne rzeczywistości, jakimi są mistyczne małżeństwo i relacje małżeńskie w ogóle mają ze sobą coś wspólnego i czy tak odmienne rzeczywistości można ze sobą zestawić? Należy zaznaczyć, że niniejsze opracowanie jest pierwszą częścią dyptyku i dopiero w drugiej znajduje się odpowiedź i jej uzasadnienie. Ta część, która przyjmuje formę prologu, wyjaśnia, czym jest mistyczne małżeństwo i jak się ono kształtuje między Jezusem a św. siostrą Faustyną. Teologiczne wyjaśnienie bazuje przede wszystkim na myśli św. Jana od Krzyża i św. Teresy. Mistyczne małżeństwo jest szczególnym zjednoczeniem człowieka z Bogiem. Wiąże się z nim wiele łask, ale również niemało trudności a nawet cierpień zarówno zewnętrznych, jak i wewnętrznych poprzez przechodzenie przez „noc zmysłów” i „noc ducha”. Niniejsze opracowanie, bazując na treści Dzienniczka, wykazuje, że siostra Faustyna przyjmowała wszystkie doświadczenia w duchu ogromnej pokory, posłuszeństwa, ufności, zawierzenia realizującego się w całkowitym poddaniu własnej woli pod wolę Bożą. Takie zachowanie stało się fundamentem do budowania głębokich relacji z Jezusem osiągające swój szczyt w mistycznym małżeństwie.

Słowa kluczowe: mistyczne małżeństwo; Jezus Chrystus; św. s. Faustyna; relacje małżeńskie.

Abstract. Understanding of essence mystical marriage of Jesus Christ and St. Faustina as a prologue to further consideration on the development of love and marital relationships. Looking at the title of the article, the reader may wonder whether such two different realities which are mystical marriage and marital relations, if at all they have something in common and whether such different realities can assemble together? It should be noted that this study is the first part of a diptych and in the second there is an answer and its justification. This part, which takes the form of a prologue, explains 
what is mystical marriage and how it shapes between Jesus and St. Sister Faustina. The theological explanation is based primarily on the thought of St. Augustine. John of the Cross and St. Teresa. Mystical marriage is a special union of man with God. This raises the many graces, but also quite a few difficulties and even sufferings of both external, and internal through passage by the "night of the senses" and "spirit night". This analysis is based on the content of "Diary" shows that Sister Faustina accepted all the experience in the spirit of immense humility, obedience, trust, entrusting implementing a complete surrender their own will to the will of God. This behavior has become the foundation for building a deep relationship with Jesus reaching its peak in the mystical marriage.

Keywords: mystical marriage; Jesus Christ; st. Faustina; marital relationships.

\section{BIBLIOGRAFIA}

Faustyna Kowalska, Dzienniczek.

Garrigou-Lagrange R., Trzy okresy życia wewnętrznego wstępem do życia w niebie, Niepokalanów 2001, s. 837.

Jan od Krzyża, Pieśń duchowa.

Jan od Krzyża, Żywy płomień miłości.

Konferencja Episkopatu Polski, Dyrektorium duszpasterstwa rodzin, Warszawa 2003, nr $18-23$.

Listy świętej Siostry Faustyny, wyd. 2, Kraków 2005.

Machniak J., Zaślubiny duchowe, w: Mistyka, w: Encyklopedia katolicka, t. XII, Lublin 2008, k. 1322-1323.

Misiurek J., Mistyka, w: Encyklopedia katolicka, t. XII, Lublin 2008, k. 1318.

Paszkowska T., Zaślubiny duchowe, w: Encyklopedia katolicka, t. XX, Lublin 2014, k. 1263.

Tomasz z Akwinu, Suma teologiczna, I-II, g. 68, a. 2.

Wspomnienia o świętej Siostrze Faustynie Kowalskiej ze Zgromadzenia Matki Bożej Miłosierdzia, wyd. 2, Kraków 2015, s. 184. 